\title{
Common Worlding Pedagogies: Opening Up to Learning with Worlds
}

\author{
Affrica Taylor, Tatiana Zakharova, and Maureen Cullen
}

\begin{abstract}
Affrica Taylor is a founding member of the Common Worlds Research Collective and an adjunct associate professor with the Centre for Sustainable Communities, University of Canberra, and the Centre for People, Place and Planet, Edith Cowan University. She has a background in Indigenous Australian education and a $\mathrm{PhD}$ in postcolonial geography. Both have shaped her abiding interest in the interdependent relations among people, place, and other beings and entities on damaged settler colonized lands, and in the need to decolonize these relations in ecologically precarious times. She has published three books and many articles on these themes. Email: Affrica.Taylor@canberra.edu.au
\end{abstract}

Tatiana Zakharova, MLA, is a playground designer and is pursuing her PhD in the Faculty of Education at Western University, London, Ontario. Tatiana's research focuses on the entanglement of pedagogy and design. In her multidisciplinary work, she thinks with feminist posthumanist scholars to trouble the notion of play as a means of progress, imagining instead relationship-attuned play as worlding. Her work is a collaborative experimentation, as it wishes to reimagine play/grounding potentialities in wondering how can we respond, through both design and pedagogy, to the question of living [well] together. Email: tzakharo@uwo.ca

Maureen Cullen is an early childhood educator and a professor of early childhood education at Fanshawe College. She has a bachelor's degree in early childhood leadership, MA in education from Western University, and is pursuing a PhD in curriculum studies at Western University. Some areas of research that interest her are the practices of early childhood educators and curriculum making with young children in ways that move toward reconstituting relations and exploring possibilities with human and more-thanhuman others. Email: mcullen2@uwo.ca

Common worlding is a collective pedagogical approach. It is also a deliberate move to open up education to worlds beyond narrow human preoccupations and concerns and beyond its standard framing as an exclusively social practice. In this article, we identify some of the guiding principles that underpin this approach and explain how they work out in practice. We do so by offering a selection of illustrative vignettes drawn from the Walking with Wildlife in Wild Weather Times early childhood research project in Canberra, Australia, and from the Witnessing the Ruins of Progress early childhood research collaboratory in Ontario, Canada.

Key words: common worlding; multispecies pedagogies; walking methods; place stories; speculative mapping; decolonizing pedagogies
Common worlding is a collective pedagogical approach that deviates significantly from the individualistic and humancentric developmentalist charter that dominates early childhood education. At the most fundamental level, it is a move to open up education to worlds beyond narrow and self-serving human preoccupations and concerns and beyond its standard framing as an exclusively social practice. Common worlding pedagogies recognize that children grow up, live, and learn within more-than-human worlds-within complex and diverse ecological communities, not just in human societies. Our common worlds are the interdependent, life-sustaining ecological communities that we share with all manner of other beings, entities, and forces on earth. In recent times, they have become increasingly destabilized. In some cases, they have been critically threatened by acts of self-serving human ignorance and greed, as evidenced by the current crises of global warming and mass extinctions. Common worlding is an ecologically attuned and recuperative pedagogical approach that seeks to make education relevant and responsive to the planetary-scale ecological challenges that all children now face-no matter where they live. 
In this article, we outline some of the significant ways in which common worlding approaches depart from developmentalist orthodoxies. To illustrate these departures, we offer some examples from Australian and Canadian early childhood education programs in which we have taken part. As common worlding pedagogies cannot be reduced to techniques and lesson plans alone, there is no teachers' manual to refer to. They rely on an openness to seeing ourselves as members of the wider ecological community in which we live. They require that, as teachers and learners, we deepen our own understandings of our relations with the more-than-human world around us and find our own ways of incorporating this understanding into our everyday pedagogical practices.

That said, a number of ethical principles, or beliefs, guide our early childhood common worlding pedagogies. These have been informed by years of experimental pedagogical practice and are thoroughly elaborated in previous works (see, e.g., Common Worlds Research Collective, 2020; Hodgins, 2019; Pacini-Ketchabaw \& Taylor, 2015; Taylor, 2017a, 2017b; Taylor \& Pacini-Ketchabaw, 2015a, 2015b, 2018). They have also been shaped by our engagement with the thinking of First Nations and feminist scholars from a wide range of disciplines (e.g., Haraway, 2008, 2016; Le Guin, 1986/2020; Martuwarra RiverOfLife et al., 2020; Liboiron, 2021; Massey, 2005; Plumwood, 1993; Rose, 2011; Shotwell, 2016; Stengers, 2015; Tallbear, 2015; Tsing, 2015; Tuhiwai Smith et al., 2019). We are indebted to them.

The following list of principles is far from exhaustive but nevertheless identifies a number of key axioms that underpin our common worlding pedagogical practice.

- Common worlding pedagogies are generated through curious, creative, and collaborative interactions with the multifarious worlds around us. They do not follow prescribed curricula. Instead they unfold through real-life encounters.

- Common worlding pedagogies strive to find ways of thinking and learning with the worlds around us. They try and avoid teaching about the world (out there) as if it is a singular knowable entity which we are separate from and superior to.

- Common worlding pedagogies are primarily concerned with our relations with other beings, entities, and forces. They are not framed by human development theories, nor are they centered around individual learners. They are collectively oriented.

- Common worlding pedagogies take an ecological world view. They stress the interconnection of all earthly beings, entities, and forces. They resist divisions_-such as between subjects and objects or nature and culture-that separate human learners off from the world that they study.

- Common worlding pedagogies respond to global and local ecological challenges. They seek ways of recuperating settler-damaged worlds in collaboration with First Nations peoples and the land itself, not through grandiose and instrumentalist Western science techno-fixes.

- Common worlding pedagogies contribute to the ongoing process of decolonizing pedagogies. They recognize that the lands we now occupy have been stolen from First Nations peoples and that ecocide is inextricably linked to Indigenous dispossession and cultural genocide. They work to uncover multiple modes of knowing beyond dominant settler colonial narratives. They foreground stories that have been erased by the singular, dominant perspective of totalizing, settler colonial narratives.

- Common worlding pedagogies are concerned with the common good and with finding ways of learning how to live well together with our differences (human and more-than-human). They are neither individualistic 
nor competitive.

To show how we put these principles into practice, we provide a brief overview of two different early childhood common worlding pedagogical research projects in which we have been involved. We illustrate them with select vignettes. These are drawn from the ongoing pedagogical documentation we have produced in the course of undertaking these projects.

\section{Walking with wildlife in wild weather times}

The first example is an Australian research project called Walking with Wildlife in Wild Weather Times that I (Affrica) undertook with my colleague Tonya Rooney (from Australian Catholic University) from 2017 to 2018. Over a period of 18 months, we went on fortnightly walks with a group of preschool children and their teachers in a lakeside grassy woodlands urban reserve on the Australian National University campus, close to the civic centre of Canberra. This is Ngunnawal country.

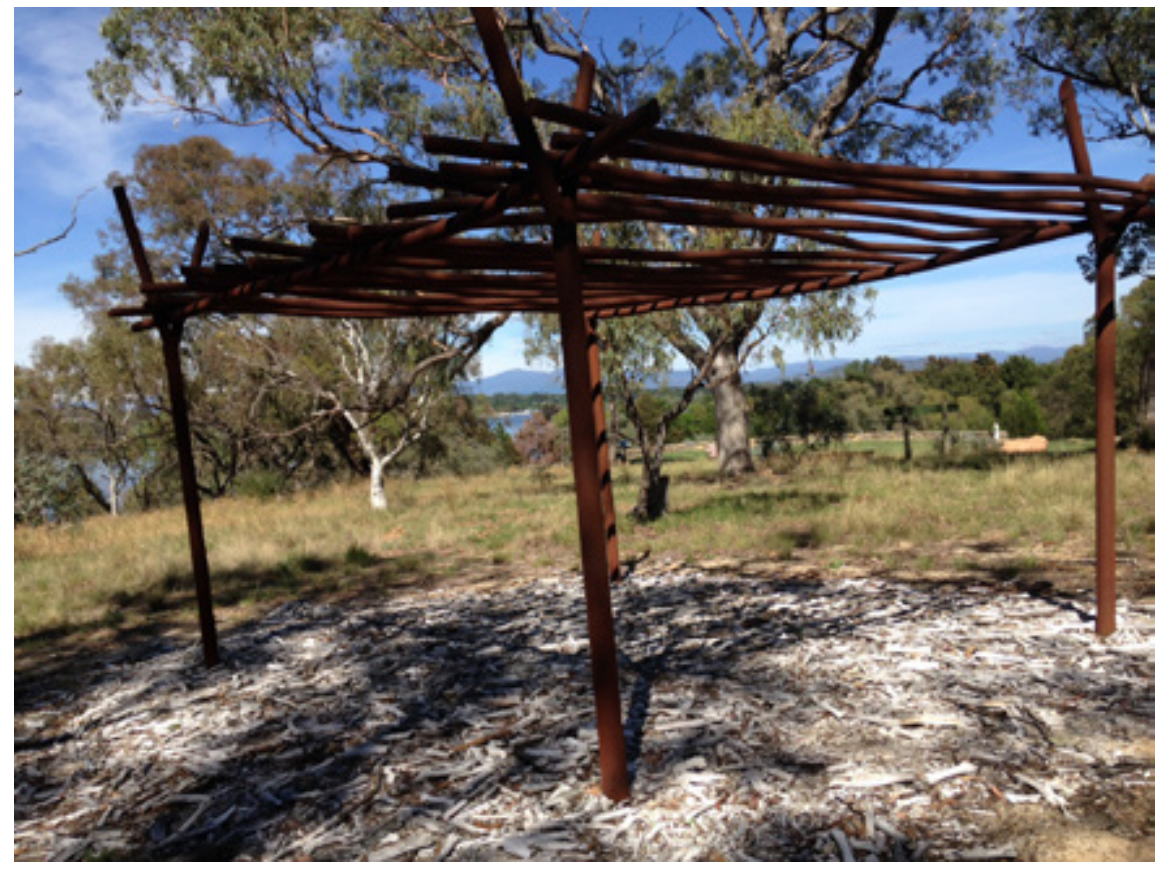

Figure 1. Ngaraka: Shrine for the lost Koori.

At the beginning of each walk, we visited a First Nations sculpture in this reserve called Ngaraka: Shrine for the Lost Koori (Mundine \& Foley, 2001) and paid our respect to the Ngunnawal people who have walked and cared for this country for millennia (see Figure 1). This regular shrine visit helped us to orient ourselves toward the ancestral and ongoing presence of the First Nations Ngunnawal people of this country. It was a ritual that enabled us to enact a practice that Fikile Nxumalo (2016) refers to as refiguring presences, or bringing back into consciousness the presence of those who are often forgotten or rendered invisible. The children were always drawn to handle and inspect the kangaroo bones scattered around the base of the shrine. These bones served as a material reminder that the ground on which we walk is literally composed of the bodies of others who came before us, and that we always walk in their footsteps (see Instone \& Taylor, 2015). The past is always in the present. We just need to learn how to look for and recognize it.

We also need to remember that it is not just us humans who walk, traverse, and shape country. By adopting 
multispecies walking methods (see Ingold \& Vergunst, 2008; Kirksey \& Helmreich, 2010), we paid close attention to the plants and animals that live in this place, noticing their movements and interactions, sometimes in response to our encounters with them but also independent from us. We looked for traces and signs of the intersecting multispecies stories of this place (van Dooren \& Rose, 2012). The children needed very little encouragement to do this; in fact, they showed us how it is done. As they enthusiastically explored every part of these grassy woodlands, Tonya and I observed their interactions with the urban wildlife, with the natural features, and with other material objects in the landscape. We noted the multispecies pedagogical relationships that emerged through such interactions and also how these dynamic relations were affected by the changing elements and weather patterns. We learnt a lot about common worlding pedagogies from observing these interactions and recorded them in an online research blog (Taylor \& Rooney, 2017).

The purpose of this project was to design a different kind of environmental pedagogy-a slow, sustained, decolonizing, and more-than-human relational pedagogy that accords with common worlding principles and which might contribute, in some small ways, to supporting new and recuperative ways of living and learning with other species in "the new climatic regime" (Latour, 2018). We did not want to revert to teaching children about the natural world as if it exists "out there," so we deliberately avoided using environmental science texts or programs that reinforce a sense of division between us (the teachers and learners) and the environment as the thing we are teaching and learning about. Instead, we started from the time-immemorial premise held by First Nations peoples everywhere and more recently articulated by non-Indigenous environmental philosophers-that far from being separate from the natural world, we are already an integral part of the local ecology, and our human lives and fates are inextricably bound up with those of the other beings and forces around us (see, e.g., Plumwood, 1993; Rose, 2012). In line with this shift from learning about to learning with, we focused on the pedagogical affordances of the everyday relations that unfolded on the walks.

As we returned to the same places over and again on these walks, the children routinely crossed paths and interacted with local wildlife across the seasons and in varying weathers. They became more and more familiar with the plants and animals that lived there and more and more involved in the everyday events and dramas of this place. They also felt themselves to be more and more comfortable and integral members of this local ecological community. The following vignette, a descriptive snapshot drawn from our online pedagogical documentation, illustrates the kinds of things that happened on the walks. It was published on the research blog in late winter 2016, six months into the project.

We started this walk by following our noses-like dogs do-and immediately stumbled across some sweet-smelling signs of spring-to-come! A flowering daphne bush and a lone bunch of jonquils. We experimented with rubbing leaves between our fingers and sniffed the oily scent that they left on our hands.

A small pack of "dogs" ran into the tree cubby to have a quick sniff around, but after noting the damp smell of bark and a whiff of wet rabbit poo-everyone seemed to burst into faster-paced animal play. There was more yapping, leaping, bouncing, flapping, screeching and growling than smelling going on.

Standing on the lookout wall, the children took in the panoramic view-sweeping down the newly greening slope to the tall kangaroo grasslands, the large eucalyptus trees, the lake, and beyond to the distant mountains. "It's beautiful" one boy observed as he gazed out. At the bottom of the hill, we caught sight of the first rabbits we'd seen out and about for ages. They were just little dots, cautiously hopping around the edges of the long grass where they love to hide. Below the rise, some of the children spotted some leafy branches sticking out on an odd angle.

As they ran down the hill, the full story revealed itself. It was a whole clump of toppled eucalyptus trees. "The big storm must have blown them over" someone observed. It was clearly the work of a massive force, for the trees had been lifted out by their roots and smashed to the ground. Their broken limbs were lying about, all entangled. In the stillness of the 
aftermath, we could only imagine the scale and force of the storm that caused this destruction. It was quite sobering.

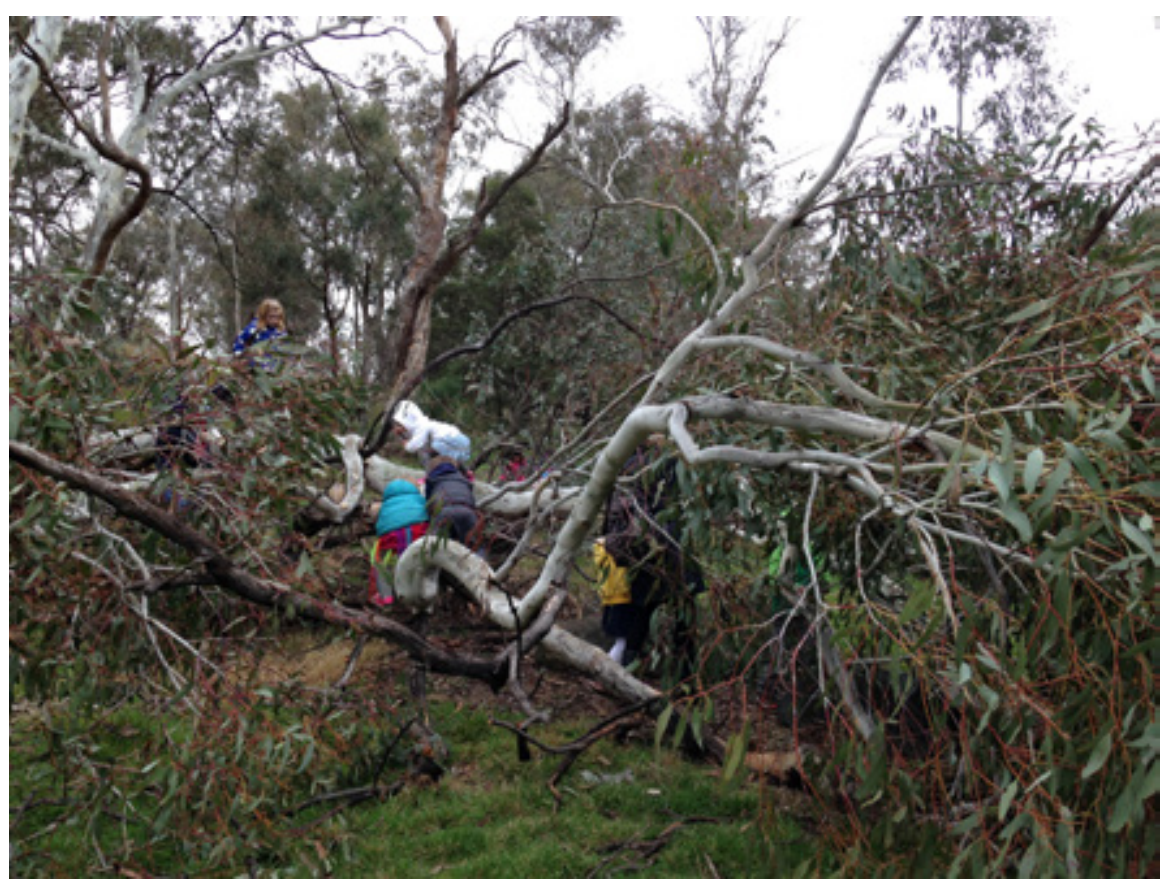

Figure 2. The children swarmed over the fallen trees.

After a moment of reflection, the children swarmed over the fallen trees (see Figure 2). Everything was at eye level so there was much to see. They inspected the mangled branches (see Figure 3), the exposed roots (see Figure 4), the crumbling bark and soil, the wrinkled elbows on the trunks (see Figure 5), the marks and bugs on the leaves. It didn't take long before they were wrapping their own limbs around those of the entwined trees.

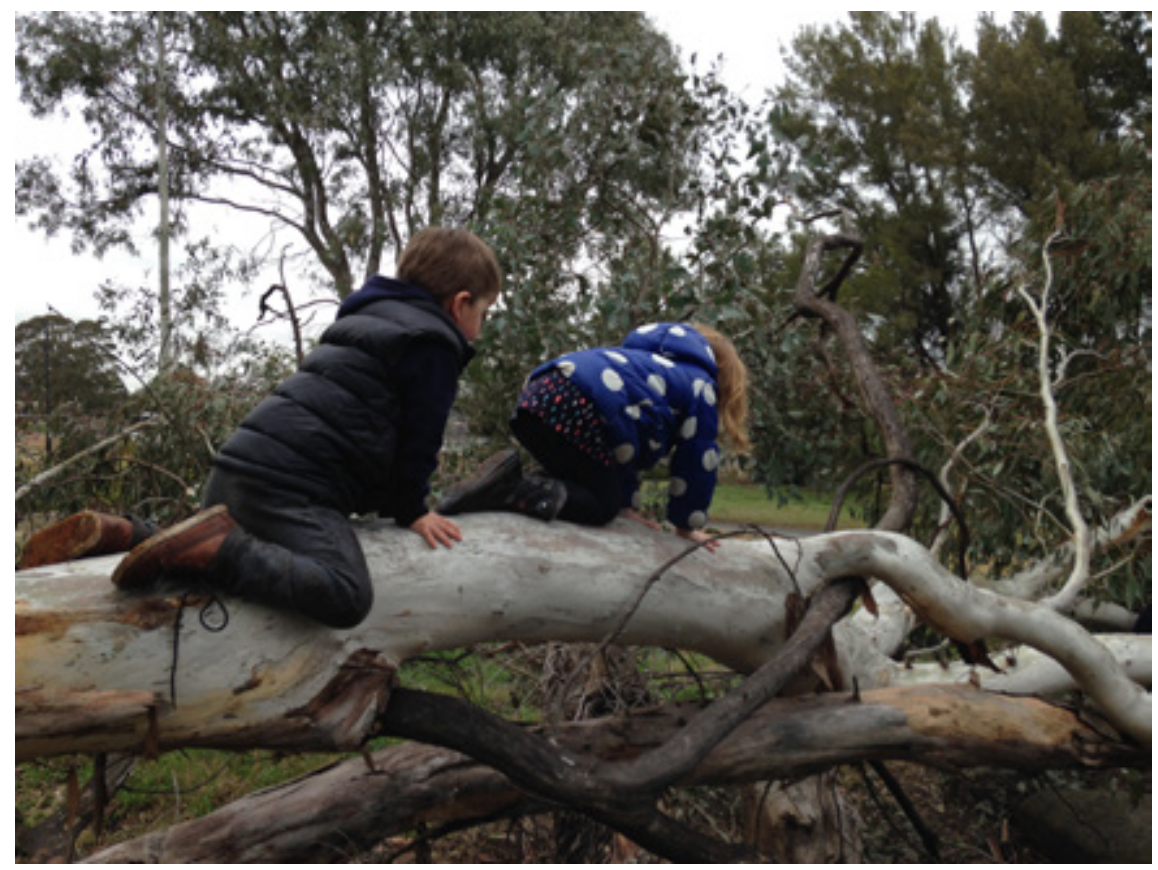

Figure 3. Inspecting the mangled branches. 


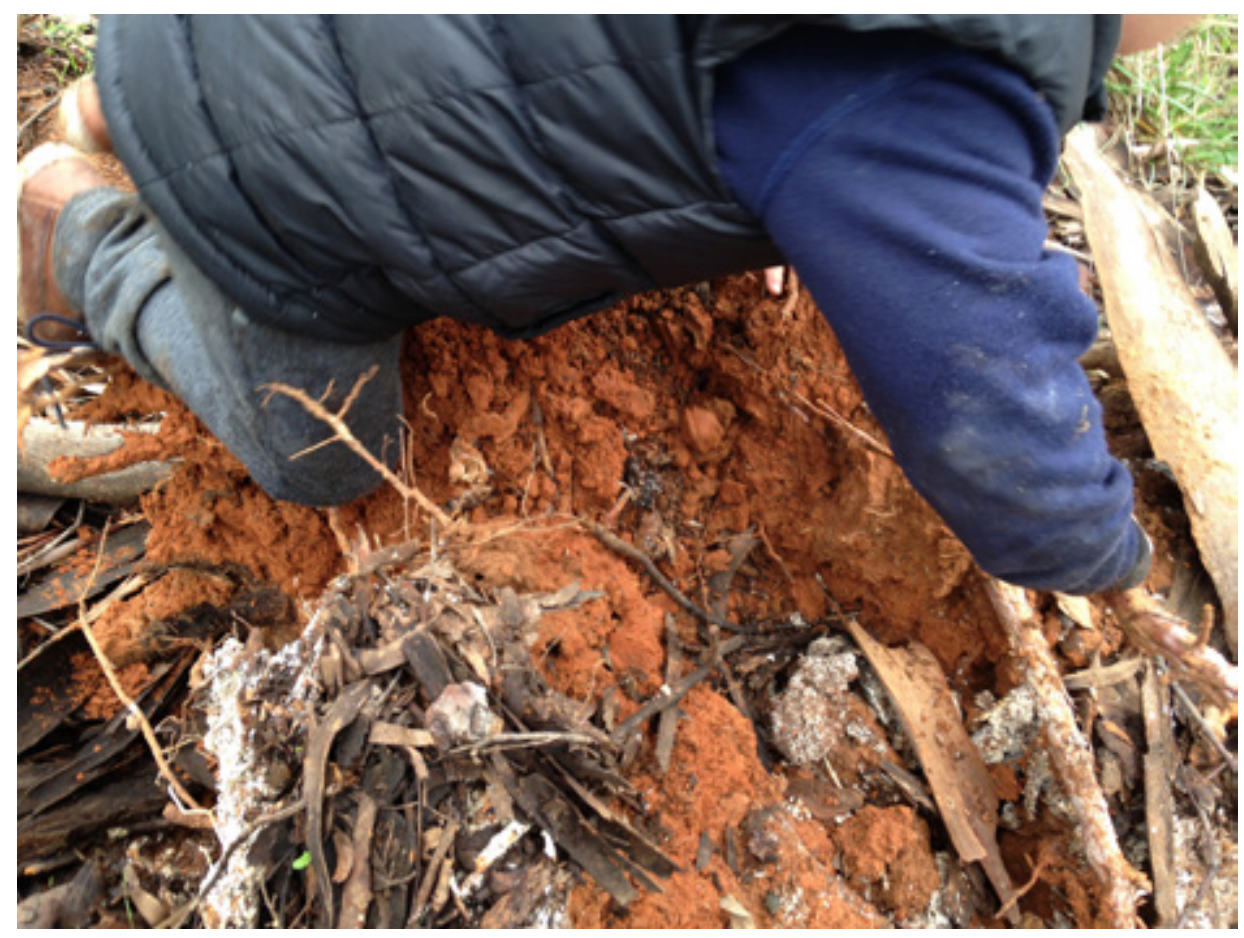

Figure 4. Inspecting the exposed roots.

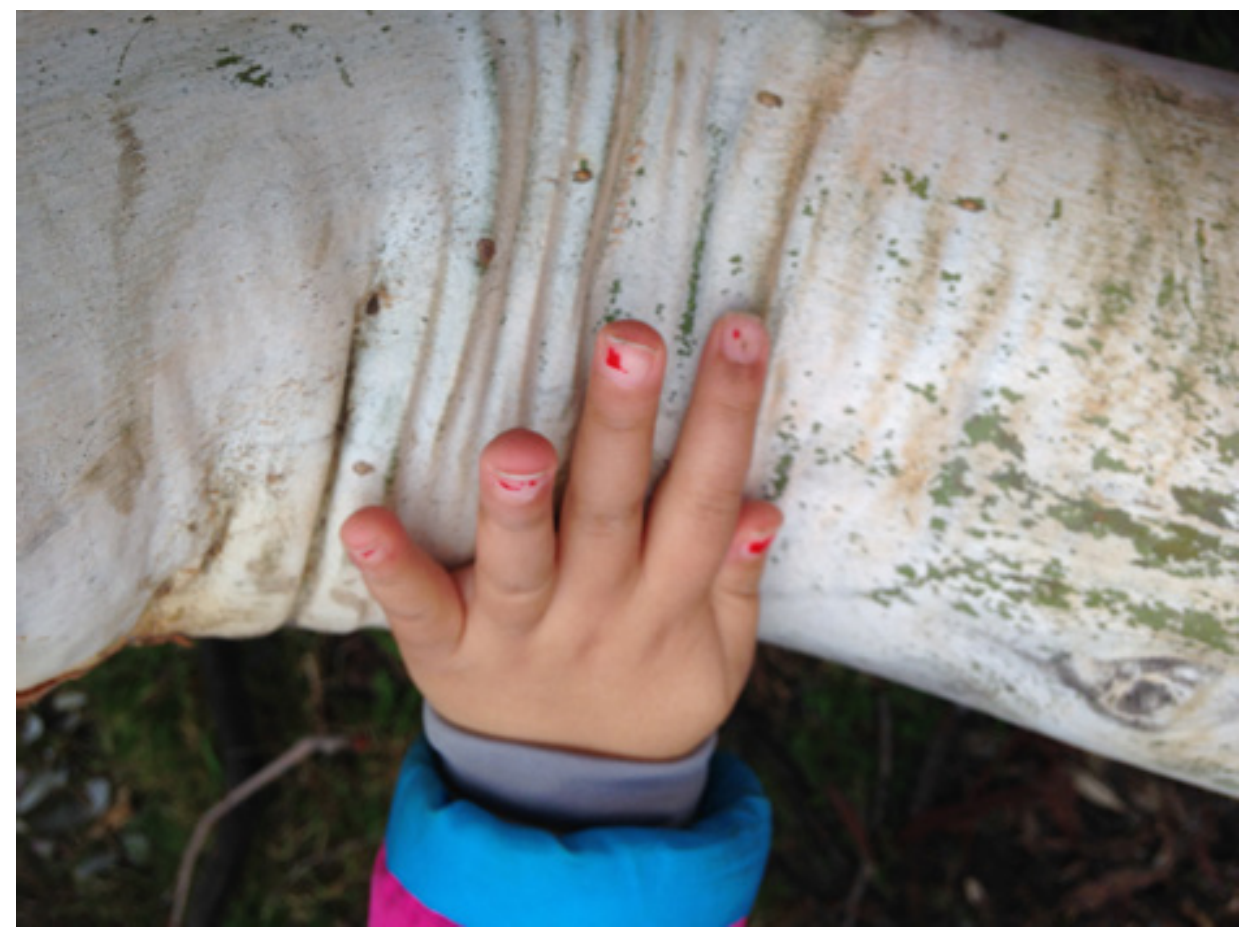

Figure 5. Feeling the wrinkled elbow. 
They spent a long time climbing along the horizontal branches, straddling them, wriggling along on their bums, lying on their tummies and gripping with their arms (see Figures 6 and 7). They were immersed in the experience of becoming tree creatures. A group of the tree climbers turned into growling "tree bears" and one boy became a whistling bird. His whistles seemed to prompt a nearby magpie to break into song.

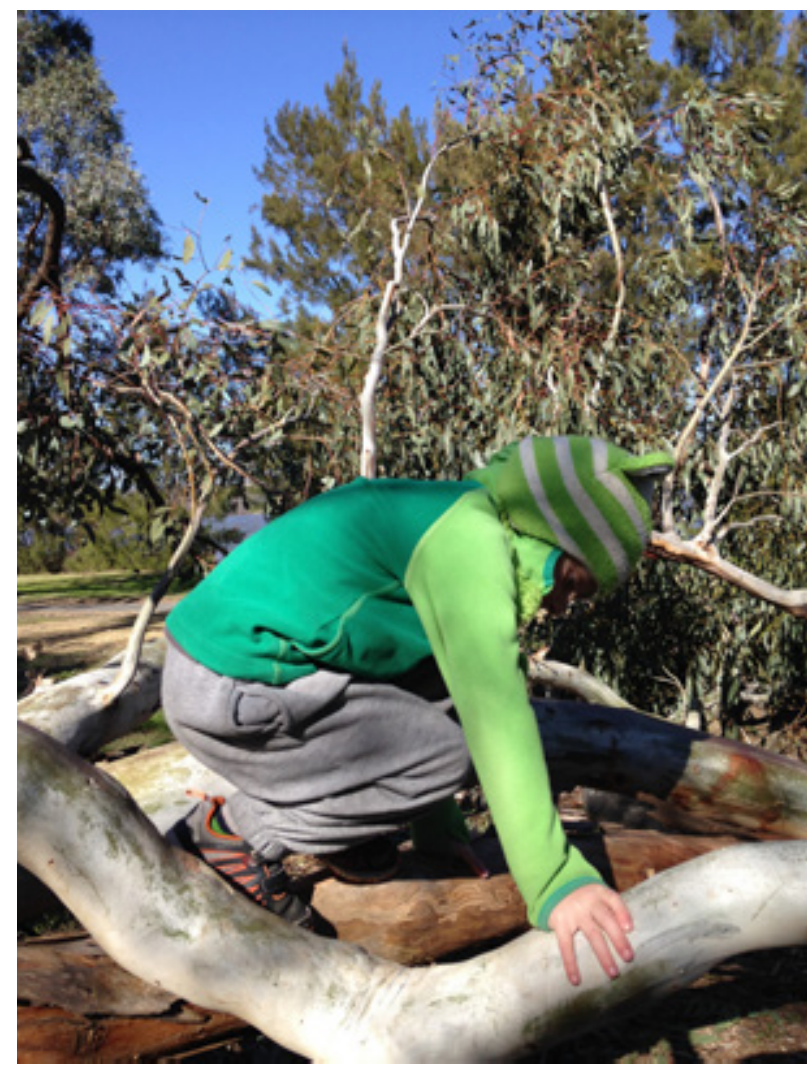

Figure 6. Straddling branches.

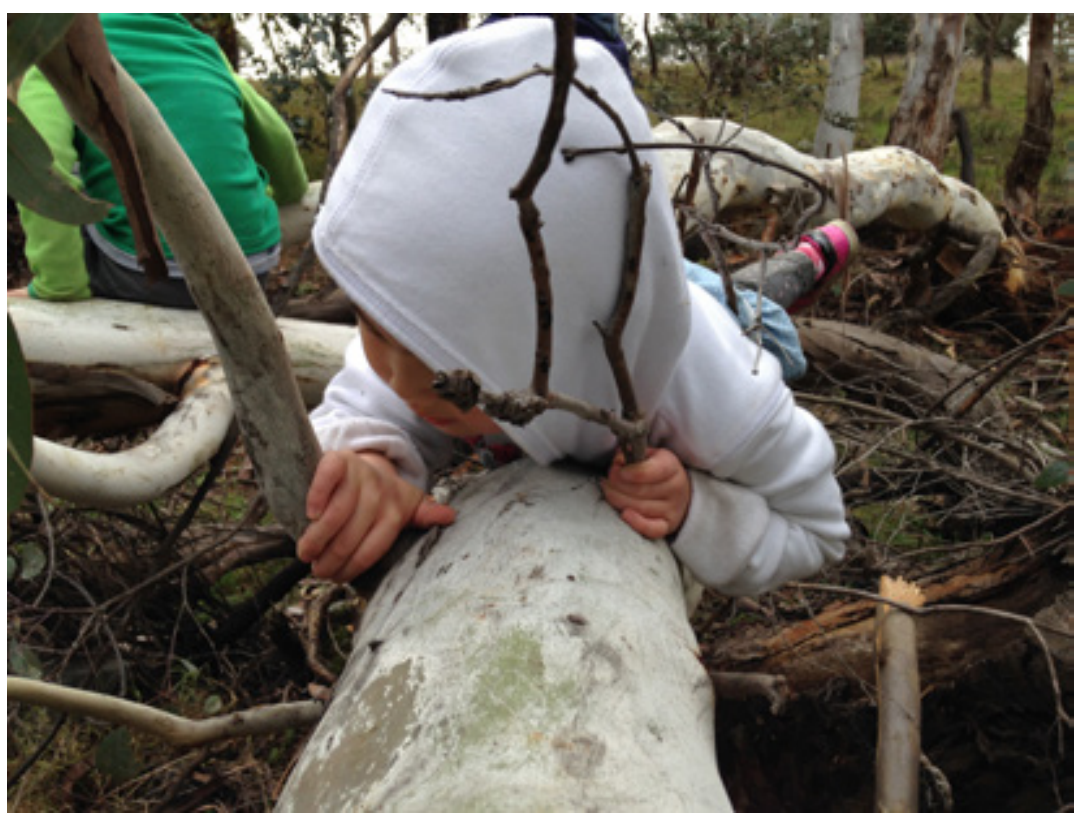

Figure 7. Lying on tummies. 
The children could have played here for hours, but lunchtime was fast approaching. Reluctantly, they dragged themselves away and made their way back up the hill towards the centre, already eagerly planning to revisit these same fallen trees on the next walk.

This vignette gives a small taste of the kind of wildlife and wild weather encounters the children experienced on the walks. There were multitudes of others over the course of the project (see Rooney, 2019; Taylor, 2019a). But even the brief details of this one eventful walk convey how the dynamic nature of the local environment captures the children's curiosity and draws them in to learn with it in collaborative, interactive, embodied, and multisensory ways. This pedagogical experience was not planned. It unfolded through unexpectedly coming face to face with the powerful consequences of elemental forces. The children were clearly affected by the storm-ravaged trees, compelled to get as close as possible to them and interact with them in a range of physical and sensory ways. They did so through inspecting, smelling, touching, listening, through wrapping their own limbs around those of the trees and becoming part of this entangled and weather-ravaged multispecies community—through joining not separating.

\section{Speculative mapping of children's place stories}

Like the Australian common worlding project, the work in Canada is also structured around preschool children's everyday encounters during walks through their local neighbourhood. However, in this case, the neighbourhood is a new suburban residential development: a grid of streets and look-alike houses punctuated by patches of forest, leftovers from hedgerows that separated former farm fields. Our (Tatiana and Maureen's) small study focuses on speculative mapping: paying attention to and layering of the children's place stories that emerge during these walks, as a way of crafting pedagogies that are responsive to the complexity of place. We think through place's constructive potentialities and histories, its "loose ends and missing links" always in process (Massey, 2005), where patterns of different worlding possibilities emerge as imaginations, and "facts" compost and compose together (Haraway, 2016).

The work is part of the Witnessing Ruins of Progress collaboratory, based in Ontario, one project within a large multinational cluster of Climate Action Childhood Network SSHRC-funded research studies (Climate Action Childhood Network, 2021). As the name suggests, this research network aims to generate pedagogies that engage with the complexity of issues related to climate change. Our Canadian component project addresses the connections among place, the stories we tell about place, and climate change through mapping the "ruins" created by settler colonization and neoliberalism in the name of "progress and development" (see Tsing, 2015).

We, the researchers and educators involved in this project, are white settlers working with settler children. So, as this project brings us into intimate proximity with (a particular piece of) land and what we conjure as its ideation as a material-discursive place/maps/stories, we are reminded that our work must remain laden with everyday refusal to take comfort in thinking that our critical anticolonial orientations are "enough." Our labour is an ongoing, although "always incomplete" response (Nxumalo, 2019, p. 160), as we burn with the need to reconcile orientations and actions and avoid the tokenistic and superficial uptake of decolonization as metaphor (Tuck \& Yang, 2012) that has been evident in early-childhood education. Like Affrica, and following Nxumalo (2016, 2019), we also work with refiguring presences as both an anticolonial orientation and a practice for decolonizing place. We conduct our pedagogical research with educators and children in an early years learning centre located in a newly built neighbourhood in a city in southwestern Ontario. Suburban mazes like this one are springing up on the outskirts of the city, replacing farm fields that were, in turn, carved out of unceded lands of First Nations peoples: Anishinaabek, Haudenosaunee, Lūnaapéewak and Attawandaron peoples. 
Our research, pedagogical work, and everyday moments with children are united by situating educational practices in a particular place and, simultaneously, situating place within particular educational practices. Place stories offered to us by children are taken seriously as a contribution to this practice in so far as they become the web that captures our everyday dwelling within our place and time. Our intent is to craft pedagogies that are responsive on both global (climate change, human/nonhuman relations, colonization, urbanization) and local (within/ of a particular educational setting) scales. By mapping children's place stories within these pedagogies, we also intend to foreground alternative stories that are often overlooked within the dominant developmental pedagogical narratives (see Land et al., 2020; Vintimilla \& Pacini-Ketchabaw, 2020).

Working within the common worlding framework we discussed in the introduction, we are guided by two principles. First, we resist the divide between nature and culture by intentionally merging the outdoor walks (nature) and indoor classroom (cultural) activities. Second, we avoid reinforcing dominant Western totalizing narratives. In this case we challenge the map as a transcendent "view from above" (Haraway, 1988) and closedended instrument of the colonial gaze, which charts and reinforces dominant Western representations of place as knowable, measurable, and claimable. The particular map we wish to tear through, cover over, tease apart, and blow up, an image that was captured via satellite by a corporation that wishes to "efficiently" navigate our daily movement, is the very manifestation of Doreen Massey's (2005) poetic and prosaic musing over a problem that "comes if you fall into thinking that that vertical distance lends you truth" (p. 107). We wish to rage against the colonial mountaintop cataloguing stance that aims to render landscape "a dormant machine waiting to be cranked into activity" (Pratt, 1992, p. 149). Instead, the mapping of stories we practice with children is a process open to uncertainty, curiosity, multiple ways of knowing and storying and other-than-human influences. There is no goal of certainty-seeking, but there is an intention for muddling, wondering, not finishing, never finishing. Here, the attention we pay to children's imaginings (pumpkin eaters, Banana Tree, etc.) as they arise from encounters with place is far from admiration over children's imagination. Rather, our actions are pedagogical choices aimed at troubling the object integrity of a colonial mapping project as it zooms in on a single neighbourhood.

We print out a black-and-white satellite image of the early-learning centre and adjacent streets on a large sheet of paper. To trouble the image of the map as a flat surface, we crease it and lay half on the floor and half up the wall. To disrupt the concept of the map as a complete and accurate representation of our neighbourhood, we set out to overlay it with new lines, new words, new images, and new kinds of information. This information emerges from unconventional sources like imagination, nonhumans, and practices of wondering, noticing, and collective retelling. To gather it, we must first walk the neighbourhood, have encounters, and make our own place stories.

It is midwinter and we are slowly walking with a group of preschool children to a nearby small forest. The walk takes us past an old pumpkin patch that somehow persists from a farm now gone. At this time of the year the patch is bare, but the children know it's still there. They explain: "Pumpkin eaters have taken all the pumpkins."

Further into the new suburbs, we walk past front lawns with well-cared-for shrubbery. One showcases a pruned specimen of a single weeping white mulberry. Unlike the native Canadian red mulberry, the white mulberry is an introduced species. Hardy and tolerant of most soils, it is a regular on the list of plants recommended for children's gardens. It's advertised as a "nature-made secret hideout": "Just cut an opening in the branches, or prune shorter for easier supervision!" Last year, the homeowners decorated their weeping mulberry with Christmas ornaments, which reminded the children of bananas. They named it Banana Tree. There hasn't been anything on the tree since last Christmas, but the story remains, and a stop by Banana Tree is a must on the walks to and from the forest. Today, the children exclaim, "Somebody stole the bananas!" They trace evidence of stolen fruit through a series of rust circles on the pavement (see Figure 9). We believe they know that prized things have been taken from this place, and that their remains are etched onto the ground. 


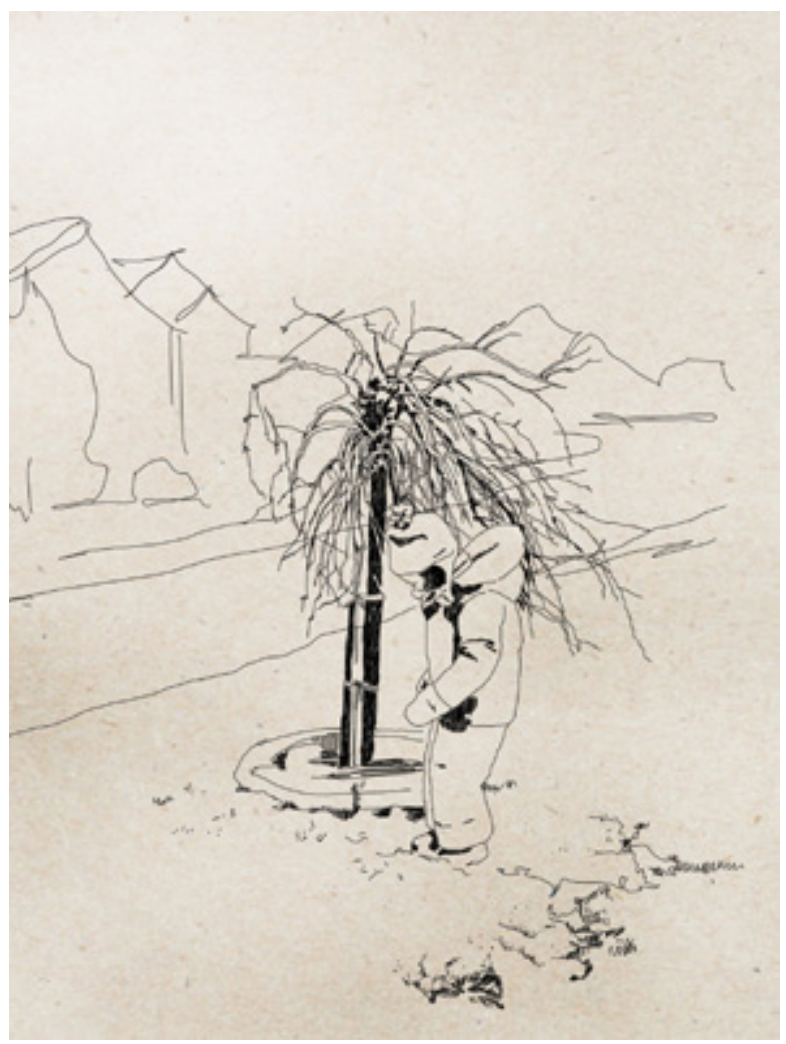

Figure 8. Banana Tree sketch.

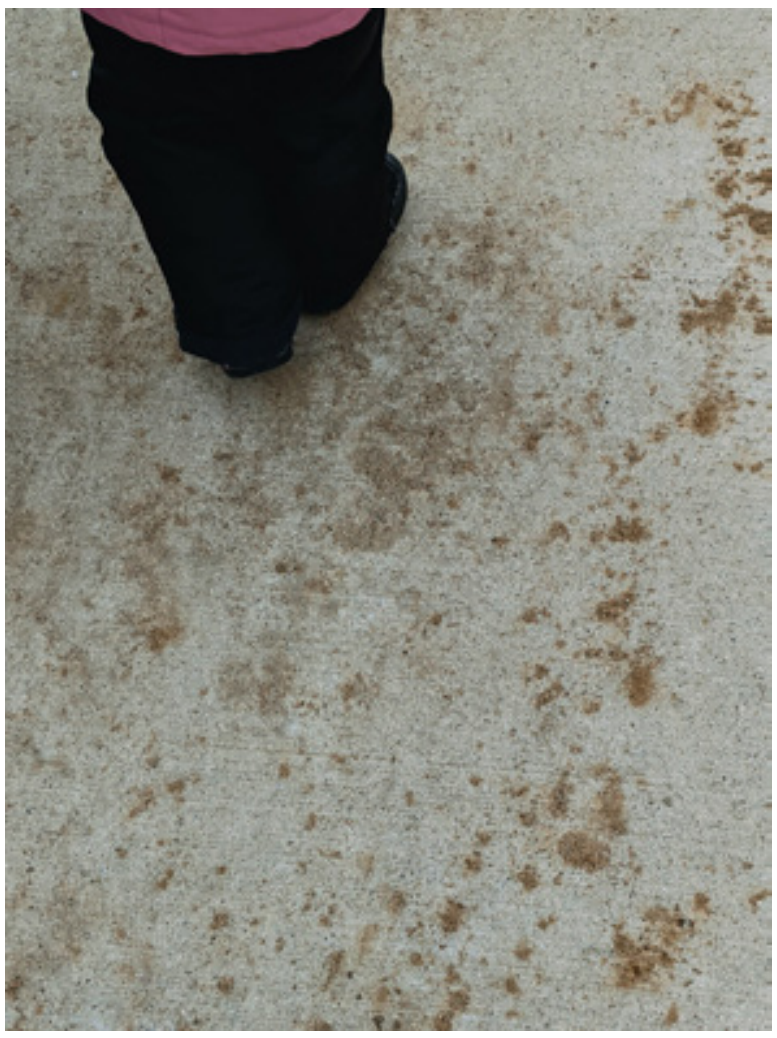

Figure 9. Following the rust. 
On another late winter day, we enter the forest with the swishing of snow pants and the clunking of winter boot heels dragging across the concrete sidewalk. "The squirrel is still died!" shouts a boy. The children stumbled upon this dead squirrel on the previous day. They find it again easily because they'd marked the spot with a discarded fluorescent orange plastic lid. Despite the frigid temperatures, the squirrel's body has further decomposed and is now covered with bugs. One child worries that the squirrel is "sad and missing his family." Another suggests that he was "asleep for a long, long day." They agree that he needs to be covered in a warm blanket of fallen leaves. The leaves are gathered and carefully placed. Everyone is quiet as the bed is marked with a large pine bough laid across the top.

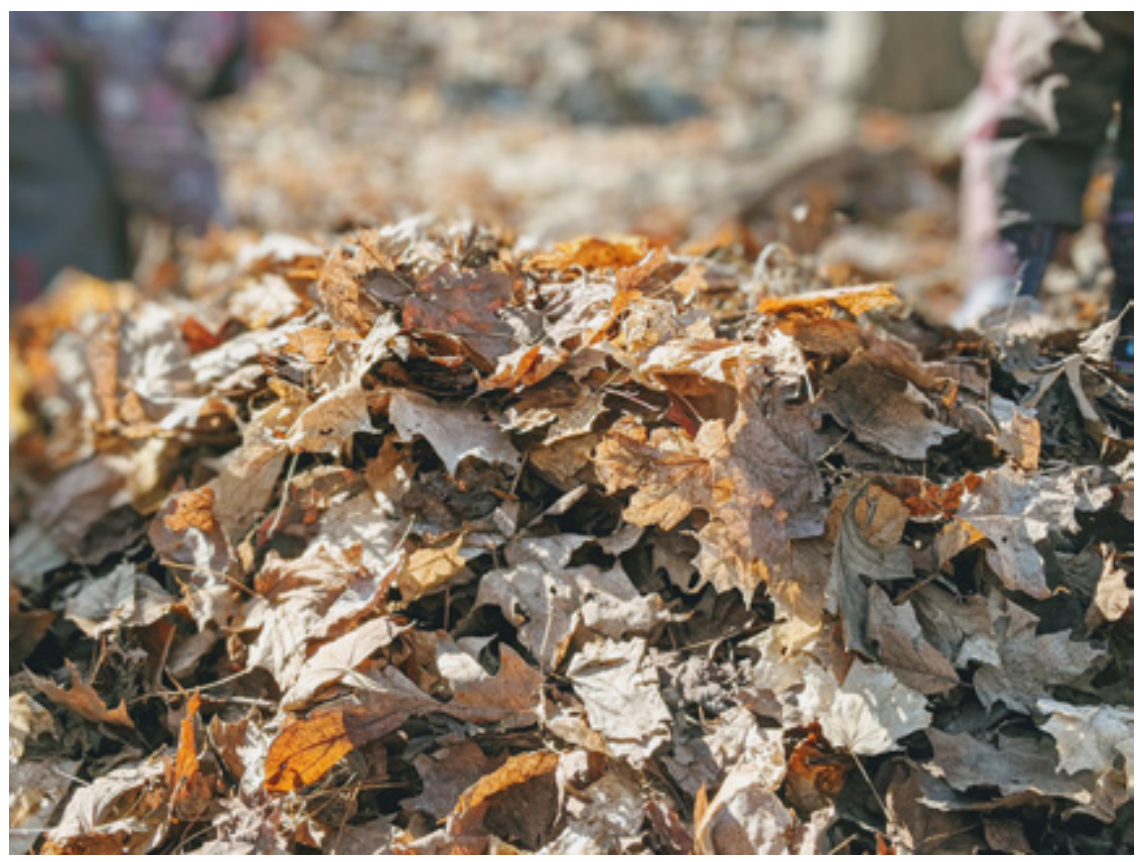

Figure 10. Squirrel under the leaves.

Back in the classroom, we gather around the map and tell the stories of the dead squirrel, the Banana Tree, the pumpkin eaters. We print photos from our walks and place them on top of our oversized map. The work from previous days is not removed. Instead, it is covered by more layers of images, paper, lines, and stories. The children use pens and charcoal pencils to draw long, light lines and forceful, thick, dark ones onto the new layer of semitranslucent vellum we have placed on top of the map. They trace these lines with their fingers and feet, pushing their weight against the paper. Multiple bodies crowd into the small space on top of the map. Foreheads are pushed against the hard surface. Pencils move slowly, and then so vigorously that they tear through the paper. The children shift their bodies to follow the lines of roads, roofs, treetops. A child steps onto the map with both feet: "I'm walking here!" There is nothing transcendent about this mapping practice. 


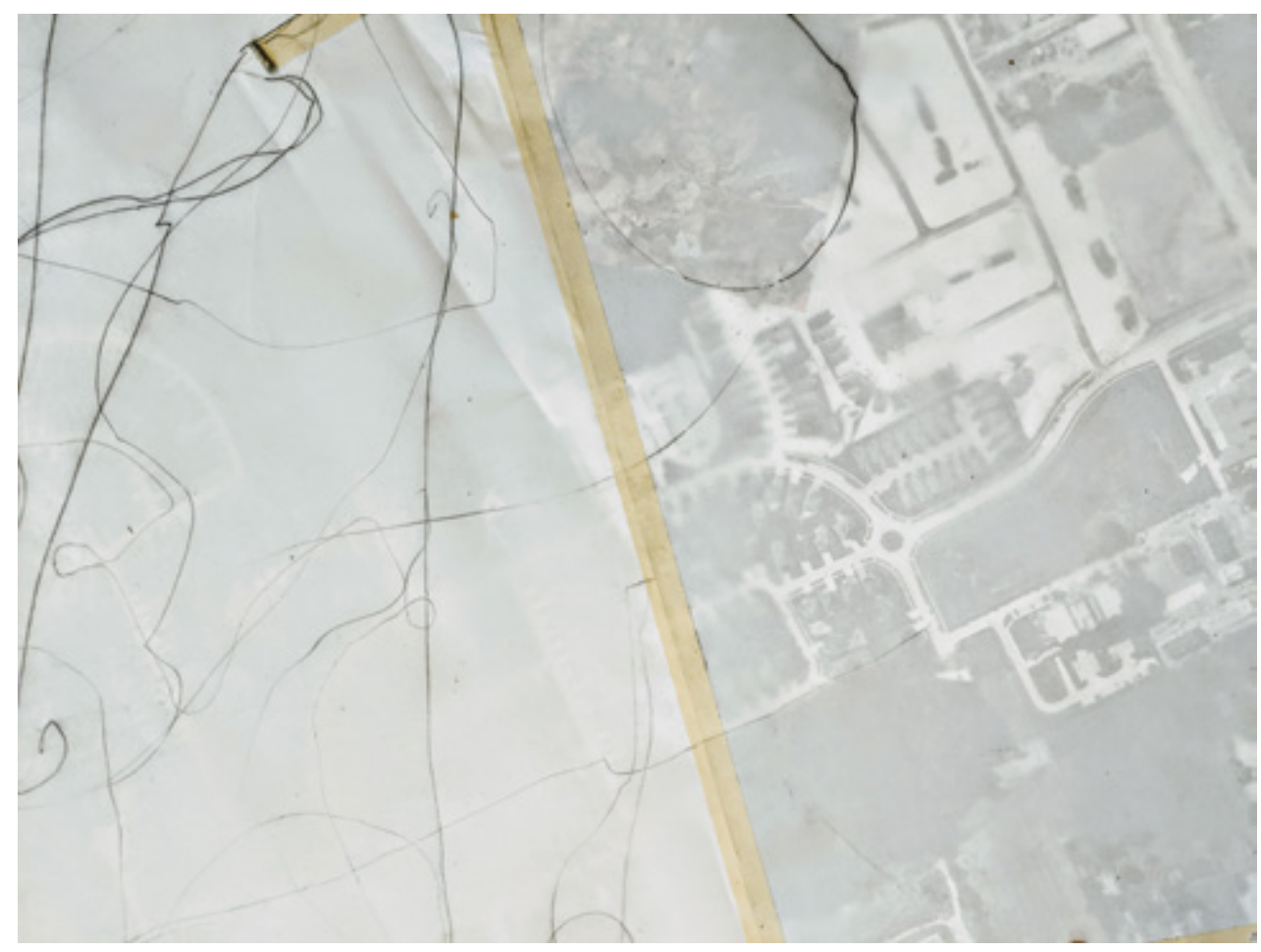

Figure 11. Mapping and tracing in the classroom.

The preceding vignettes offer a view into a common worlding pedagogy that maps children's speculative stories of everyday place encounters. Like our Australian colleagues, we did not plan or stage these encounters. They emerged when children's movements unexpectedly intersected with those of others-with living settler colonial histories, remnants of previous agricultural land use, suburban gardening practices, and debris, and with stories of loss and discovery, death, decomposition, and care. The mapping work inside the classroom reverberates with the same rhythm as our walks. It emphasizes points of view attuned to small stories of difference which have the potential to make a difference (see Le Guin, 1986/2020). Our common worlding speculative mapping does not illustrate place. It unfolds both alongside and within place, and alongside and within our own bodies, when we walk, touch, speak, imagine, speculate. Unlike the satellite map we reinscribed, our mapping vantage point is not the lofty, totalizing "view from above" looking down with authority that Donna Haraway $(1988,2008,2016)$ rails against. Rather, our mapping is embedded in the real-life grounds of place, and the children's view is an immersive one-looking around, looking out, looking in, and looking up. The pedagogical compositions of walking and speculative mapping practices are thus intensely attuned with intimate entanglements of human and more-thanhuman forces, facts, imaginings, histories, and futures.

\section{Conclusion}

Common worlding pedagogies are never about studying the world in a way that sets us (humans) apart from it or above it. As you can see from the vignettes from these two projects, they do the opposite. They open us up to the world in a way that deepens an appreciation of connectivity. They counteract the conceits and dangerous delusions of human separation and dominion that are perpetuated by dominant Western-style education systems and which have caused the current ecological crises (Taylor, 2019b). They teach us that we are one among many in our interdependent heterogenous common worlds and not the only movers and shapers of this world. They bring 
us "down to earth" (Latour, 2018).

This kind of pedagogy requires us to stay open to learning with the worlds around us in all their unfolding uncertainty. It emphasizes that we learn by being attentive to these interactive worlds of which we are part and which regularly surprise us. However, this openness to learning with and being in unpredictable worlds neither precludes nor excuses us from adhering to ethical principles and having clear pedagogical intentions. Not everything goes. In small and incremental ways, common worlding pedagogies deliberately foster the kinds of firmly grounded, anticolonial, collective and recuperative dispositions and actions that are so desperately needed in these precarious times. 


\section{References}

Climate Action Childhood Network. (2021). Witnessing ruins of progress [Early childhood education collaboratory research site and blog]. https://witnessingruinsofprogress.climateactionchildhood.net/

Common Worlds Research Collective. (2020). Learning to becoming with the world: Education for future survival. Education Research and Foresight Working Paper 28. UNESCO. https://unesdoc.unesco.org/ark:/48223/pf0000374923/PDF/374923eng.pdf.multi

Haraway, D. (1988). Situated knowledges: The science question in feminism and the privilege of partial perspective. Feminist Studies, 14(3), 575-599. https://doi.org/10.2307/3178066

Haraway, D. J. (2008). When species meet. University of Minnesota Press.

Haraway, D. J. (2016). Staying with the trouble: Making kin in the Chthulucene. Duke University Press.

Hodgins, D. (Ed.) (2019). Feminist research for 21st-century childhoods: Common worlds methods. Bloomsbury Academic.

Ingold, T., \& Vergunst, J. L. (2008). Ways of walking: Ethnography and practice on foot. Routledge.

Instone, L., \& Taylor, A. (2015). Thinking about inheritance through the figure of the Anthropocene, from the Antipodes and in the presence of others. Environmental Humanities, 7, 133-150. https://doi.org/10.1215/22011919-3616371

Kirksey, S. E., \& Helmreich, S. (2010). The emergence of multispecies ethnography. Cultural Anthropology, 25(4), 545-576. https://doi. org/10.1111/j.1548-1360.2010.01069.x

Land, N., Vintimilla, C. D., Pacini-Ketchabaw, V., \& Angus, L. (2020). Propositions toward educating pedagogists: Decentering the child. Contemporary Issues in Early Childhood, 1-13. https://doi.org/10.11771463949120953522

Latour, B. (2018). Down to earth: Politics in the new climatic regime. Polity Press.

Le Guin, U. K. (2020). The carrier bag theory of fiction. Ignota Books. (Original work published 1986)

Liboiron, M. (2021). Pollution is colonialism. Duke University Press.

Martuwarra RiverOfLife, Poelina, A., Bagnall, D., \& Lim, M. (2020). Recognizing the Martuwarra's first law: Right to life as living ancestral being. Transnational Environmental Law, 9(3), 541-568. https://doi.org/10.1017/S2047102520000163

Massey, D. B. (2005). For space. SAGE.

Mundine, D., \& Foley, F. (2001). Ngaraka: Shrine for the lost Koori [Sculptural installation]. Australian National University, Canberra.

Nxumalo, F. (2016). Towards "refiguring presences" as an anti-colonial orientation to research in early childhood studies. International Journal of Qualitative Studies in Education, 29(5), 640-654. https://doi.org/10.1080/09518398.2016.1139212

Nxumalo, F. (2019). Presencing: Decolonial attunements to children's place relations. In B. D. Hodgins (Ed.), Feminist research for 21stcentury childhoods: Common worlds methods (pp. 159-170). Bloomsbury Academic.

Pacini-Ketchabaw, V., \& Taylor, A. (2015). Unsettling pedagogies through common world encounters: Grappling with (post)colonial legacies in Canadian forests and Australian bushlands. In V. Pacini-Ketchabaw \& A. Taylor (Eds.), Unsettling the colonialist places and spaces of early childhood education (pp. 43-62). Routledge.

Plumwood, V. (1993). Feminism and the mastery of nature. Routledge.

Pratt, M. L. (1992). Imperial eyes: Travel writing and transculturation. Routledge.

Rooney, T. (2019). Weathering time: Walking with young children in a changing climate. Children's Geographies, 3(4), 177-189. https:// doi.org/10.1080/14733285.2018.1474172

Rose, D. B. (2011). Wild dog dreaming: Love and extinction. University of Virginia Press. 
Rose, D. B. (2012). Multispecies knots of ethical time. Environmental Philosophy, 9(1), 127-140. https://doi.org/10.5840/envirophil2012918

Shotwell, A. (2016). Against purity: Living ethically in compromised times. University of Minnesota Press.

Stengers, I. (2015). In catastrophic times. Resisting the coming barbarism. Open Humanities Press.

Tallbear, K. (2015). Dossier: Theorizing queer inhumanisms: An Indigenous reflection on working beyond the human/not human. GLQ: A Journal and Lesbian and Gay Studies, 21(2-3), 230-235. https://doi.org/10.1215/10642684-2843323

Taylor, A. (2017a). Beyond stewardship: Common world pedagogies for the Anthropocene. Environmental Education Research, 23(10), 1448-1461. https://doi.org/10.1080/13504622.2017.1325452

Taylor, A. (2017b). Romancing or reconfiguring nature? Towards common world pedagogies. In K. Maloney, T. Gray, \& S. Truong (Eds.), Reimagining sustainability education in precarious times (pp. 61-75). Springer.

Taylor, A. (2019a). Rabbiting: Grappling with the troubling legacies of invasion. In B. D. Hodgins (Ed.), Feminist research for 21st-century childhoods: Common worlds methods (pp. 111-120). Bloomsbury Academic.

Taylor, A. (2019b). Countering the conceits of the Anthropos: Scaling down and researching with minor players. Discourse: Cultural Politics of Education, 41(3), 340-358. https://doi.org/10.1080/01596306.2019.1583822

Taylor, A., \& Pacini-Ketchabaw, V. (2015a). Learning with children, ants, and worms in the Anthropocene: Towards a common world pedagogy of multispecies vulnerability. Pedagogy, Culture, \& Society, 23(4), 507-529. https://doi.org/10.1080/14681366.2015.1 $\underline{039050}$

Taylor, A., \& Pacini-Ketchabaw, V. (2015b). Unsettling the colonial places and spaces of early childhood education in settler colonial societies. In V. Pacini-Ketchabaw \& A. Taylor (Eds.), Unsettling the colonialist places and spaces of early childhood education (pp. 1-18). Routledge.

Taylor, A., \& Pacini-Ketchabaw, V. (2018). The common worlds of children and animals: Relational ethics for entangled lives. Routledge

Taylor, A., \& Rooney, T. (2017). Walking with wildlife in wild weather times [A common world childhoods research collective blog]. https://walkingwildlifewildweather.com/

Tsing, A. L. (2015). The mushroom at the end of the world: On the possibility of life in capitalist ruins. Princeton University Press.

Tuck, E., \& Yang, K. W. (2012). Decolonization is not a metaphor. Decolonization: Indigeneity, Education, \& Society, 1(1), 1-40. https://jps. library.utoronto.ca/index.php/des/article/view/18630

Tuhiwai Smith, L., Tuck, E., \& Yang, K. W. (2019). Indigenous and decolonizing studies in education: Mapping the long view. Routledge.

van Dooren, T., \& Rose, D. B. (2012). Storied-places in a multispecies city. Humanimalia, 3(2), 1-27. https://humanimalia.org/article/ download/10046/10484

Vintimilla, C. D., \& Pacini-Ketchabaw, V. (2020). Weaving pedagogy in early childhood education: On openings and their foreclosure. European Early Childhood Education Research Journal, 28(5), 628-641. https://doi.org/10.1080/1350293X.2020.1817235 